METAgraphias: metalinguagem e outras figuras v.1 n.1 (1) marçol2016

\title{
fragmentos sentimentais (a cena reduzida)
}

\section{Ary Coelho}

Os sentimentos fazem parte de como estamos e como entendemos o mundo à nossa volta. Todos os sentimentos fazem parte de mim? Sim, mas é muita coisa. Todo o mundo está em mim, mas não o tempo todo. Sentimentos podem ser momentos de uma coreografia. Em quem dança e em quem é tocado pela dança. Nem sempre o sentimento que se dança é o sentimento que toca o outro. Só alguns sentimentos por agora. Nem todos. Solidão. Angústia. Prazer. Desejo. Ou os sete pecados capitais. Sentimentos que transformam atitudes perante o mundo. Sentimentos que são atitudes e propostas para gerar movimentos. A vida com seus sentimentos e suas conexões humanas. As relações íntimas entre cada um com suas desconexões, sofrimentos, tristezas, alegrias. Estou buscando pensar um exercício do sensível, com intensidade necessária para a execução do gesto: quais sentimentos são suficientes? Sentimentos aparecem quando procuramos pelo ritmo corporal: espaço, tempo e ritmo. Os sete pecados capitais são atitudes humanas contrárias às leis divinas. Foram definidos pela Igreja Católica, no final do século VI, durante o papado de Gregório Magno, são eles: 1.Luxúria; 2.Gula; 3.Avareza; 4.Ira; 5.Soberba; 6.Vaidade e 7.Preguiça. Quero entender os pecados, não como pecados, mas como propostas de processos criativos para ativar o corpo. Propostas para pensar movimentos que podem ser gerados por sentimentos ou direcionamentos do sentir: 
1. Luxúria: entender o corpo fora dos costumes e das sensações do próprio corpo. Um corpo exagerado de sentimentos. Com mais sentimentos que o de costume. Um corpo preenchido de sentimentos e estranho para si mesmo. Como pensar em movimentos fora da rotina, no espaço urbano, andar na rua e não ser comum. Se arrastar na rua. Andar de costas. Fazer parte da rua como se tudo fosse corpo. Que sensação o corpo pode ter no momento atual?

2. Gula: desenvolver um trabalho de performance, ficar comendo pizza até o ponto de esgotamento, até o corpo não suportar e assumir as consequências. Vomitar pizza é performance? Exagero. 0 movimento corporal de um corpo que vomita é uma dança?

3. Avareza: montar um personagem desprovido de tudo, um mendigo, andarilho perdido no tempo e espaço, mas para se conectar com o mundo, com um certo ritmo. 0 mendigo como exemplo de uma avareza ao contrário. 0 outro, generoso consigo e sem nada do mundo.

4. Ira: ter raiva do próprio movimento, fazer uma atmosfera, que se mover e uma culpa que cria o proibido para si mesmo. Esta tensão pode ser um ponto de busca do mover.

5. Soberba: esperar e depois de passar por todas as propostas anteriores, 0 corpo já esta esgotado, buscar um movimento com leveza e ficar em movimento, pode ser um prazer de alegria e certo orgulho de si mesmo. Saber que é possível realizar movimentos a partir de sentimentos. A certeza é o suficiente.

6. Vaidade: buscar movimentos belos e fortes, mas estes estereótipos chegam em um possível ridículo. Como é pouco ser apenas belo e formal. Dança como uma linha do corpo.

7. Preguiça: depois de fazer todas as propostas, só resta dormir, não fazer nada, só esperar. 
Andar. Sentir. Desfazer. Esperar. Solidão. Som.

Palavras ou provocações de movimento, com o ritmo da fala. Com uma proposta de repetição do movimento, mesmo com a efemeridade, em primeira instância. Ao capturar o movimento, existe um pequeno controle do que é feito. Posso fazer pequenas gravações, posso me observar e mesmo contracenar com a minha própria imagem projetada ou refletida. Neste sentido, meu interesse em buscar novas possibilidades tem por intenção estar sempre experimentando. Estas palavras são sequências para o mover: posso querer outros apegos de forma exagerada, no desejo de bens materiais. Acumular apego a prazeres carnais. Sexualidade como uma disputa dos costumes. O que é ser lasciva? Comer é ter prazer. Ser superior é mesmo uma coisa que se pode escolher? O que é um sentimento necessário ao corpo humano? A raiva contra si mesmo. A vontade de vingança. A manifestação de orgulho. A arrogância excessiva. O aspecto físico. Poder conquistar a admiração. A negligência. A falta de vontade dá trabalho. Quais são atividades importantes?

Tempo. Ritmo. Tempo. Esperando. Tempo. Intuir. Perceber. 